\title{
Ürolojik Malignitelerde Lazer Kullanımı
}

\author{
Ferhat Ateş ${ }^{1}$
}

1SBÜ Sultan Abdülhamid Han Eğitim ve Araştırma Hastanesi, Üroloji, Anabilim Dalı, İstanbul

\section{Giriş}

T azer, icat edildiğinden bu yana birçok alanda kullanılLmıştır. Tıp alanında insanlığın hizmetine sunulması sayesinde de birçok tedavi uygulamasında asıl veya alternatif yöntem olarak kullanıla gelmiştir. Tıpta kullanılmakta olan çeşitli dalga boylarında farklı isimler altında laserler mevcuttur. Absorbe olduğu maddeye göre, melaninde, suda veya hemoglobinde absorbe olan farklı dalga boylarında potasyum titanil fosfat (KTP), Neodmiyum, Tulyum, Holmiyum, Erbiyum, karbondioksit gibi çeşitli lazerler vardır ve resim 1'de özetlenmektedir (1). Bu derlemede ürolojik malignitelerde lazer kullanımı özetlenecektir.

Mesane ve üst üriner sistem tümörlerinde yaygın olarak kullanılmakta olan lazer, prostat ve böbrek tümörlerinde de deneysel çalışmalarda kullanılmaya başlanmıştır. Ürolojide lazer kulanımı ilk olarak 1978'de Staehler ve ark. tarafından bildirilmiştir (2). Bu makalede mesane tümörünün $\mathrm{Nd}$ :YAG lazer ile yakılması bildirilmiştir. Mesane tümörünün lazer ablasyonu ile ilgili tek merkezli retrospektif küçük seriler literatürde mevcuttur. Holmiyum (Ho:YAG) lazerle mesane tümörünün enblok rezesiyonu 2001 yılında ilk kez Saito tarafından raporlanmıştır (3). Thulium lazerle ilk rezeksiyon ise 2008' de Gao ve ark. tarafından bildirilmiştir (4).

\section{Klinik Uygulamalar ve Sonuçları}

Mesane tümörü için farklı lazerlerin karşılaştırmalı çalışmaları mevcut değildir. Lazer ile klasik TUR mesane tümörünü (TUR-MT) karşılaştıran çalışmalar mevcuttur. Lazer ile ayaktan tedavi uygulanabileceği, lokal anestezi altında işlemin yapılabileceği ve hastanın sondasız gönderilebileceği bildirilerek avantajlı yanları ön plana çıkarılmaya çalışılmıştır. Bununla birlikte lazerin penetrasyon derinliği ile ilişkili olarak mesane duvarı normal iken barsak yaralanması olabileceği bildirilmiştir. Ayrıca sadece vaporizasyon uygulanıp rezeksiyon yapılmaz ise histopatolojik inceleme için doku elde edilemeyecektir (5). Holmiyum lazer Ho:YAG lazer ile yapılmış prospektif ve retrospektif çalışmalar mevcuttur (Tablo 1). Bu çalışmalarda en blok rezeksiyonda veya biyopsi ve fotoablasyon gibi farklı yöntemlerde uygulanmıştır. Çoğunda takip süreleri kısadır ve nüksün nerede olduğuna ilişkin ayrıntı verilmemiş, sadece toplam nüks olup olmad1ğ1 bilgisi verilmiştir. Bu çalışmalarda kanıt düzeyi de $2 \mathrm{~b}$ yi geçmemektedir (5). Holmium-YAG lazer 10W gücünde ve $10 \mathrm{~Hz}$ frekansında küçük boyuttaki mesane kanseri tedavisinde kullanılmıştır. Küçük $(<1 \mathrm{~cm})$ tümörlere vaporizasyon/ fotoablasyon yapılabilirken, 1-4 $\mathrm{cm}$ arasındaki lezyonlara ise en-blok eksizyon yapılabilir.

\section{Thulium Lazer}

Thulium lazerle yapılmış ikisi prospektif biri retrospektif toplam 3 çalışma mevcuttur $(4,10,11)$. Bu çalışmaların kanıt seviyesi 3'tür ve hasta sayıları azdır. İki çalışmada herhangi bir komplikasyon bildirilmezken, birinde mesane perforasyonu bildirilmiştir. Toplamda 1 ve 2 yılda \%30'lara varan oranlarda nüks bildirilmektedir. Klasik TUR'a göre herhangi bir üstünlükten bahsedilemez.

Thulium lazer, $2 \mu \mathrm{m}$ dalga boyunda sürekli dalgalar üreterek etki gösterir. En-blok rezeksiyon için $550 \mu \mathrm{m}$ fiber ile 5-15 W veya 30-50 W güç kullanılır. Ho:YAG lazerden daha güçlüdür, komplikasyonları ise benzerdir. Ho:YAG lazerdeki gibi En-blok tümör rezeksiyonu için kısıtlayıcı herhangi bir lokalizasyon yoktur. Koagülasyon nekrozu zonu küçük olduğu için ( $0.2 \mathrm{~mm})$, mesane perforasyon ve ekstravazasyon oranları oldukça düşüktür. Thulium lazer, diode lazer ile kombine kullanılabilir. Mevcut veriler 1şı̆̆ında Tm:YAG lazer mesane kanseri tedavisinde etkin ve güvenilirdir (12).

Mesane tümöründe Lazer uygulaması sonuçlarına göre; Komplikasyonlar \%5.1-43 arasında değişmektedir. TUR-MT ile enfeksiyon \%24, kanama \%2.8-8; transfüzyon gerektiren kanama \%0.9-13, mesane perforasyonu \%1.3-5 oranlarında görülmektedir. Ho:YAG lazerle en blok rezeksiyon yapılabilir ve patolojik inceleme için doku alınabilir. Rezeksiyon sonrası progresyon oranı için literatürde veri yoktur, nüks oranı TUR-MT ile benzer veya daha az olduğu söylenebilir. Lazerde saçılma etkisi daha az olabilir, lokal ve alan dışı nüks beklenenden az olması gerekir. Ancak genel nüks oranı TURMT ile kıyaslanabilir düzeyde ve benzerdir (5).

\section{Potassium Titanyl Phosphate (KTP):}

KTP lazer, Nd:YAG lazerin KTP kristalleri içerisinden geçirilmesi ile elde edilir. $532 \mathrm{~nm}$ dalga boyuna sahiptir. Nd:YAG lazere göre penetrasyon derinliği sınırlıdır (0.8 $\mathrm{mm}$ ). Bu durum büyük tümörlerde dezavantaj iken, yüzeyel tümörlerde avantaj sağlar. 2014 yılında yayınlanan bir makalede He ve ark. primer kasa invaze olmayan mesane tümörü (KİMK) olan 45 hastada KTP lazer kullanarak en-blok rezeksiyon yapmışlar, düşük komplikasyon ve yeterli tedavi edici etkisi ile TUR-MT'ye alternatif olabileceğini bildirmişlerdir (13). 


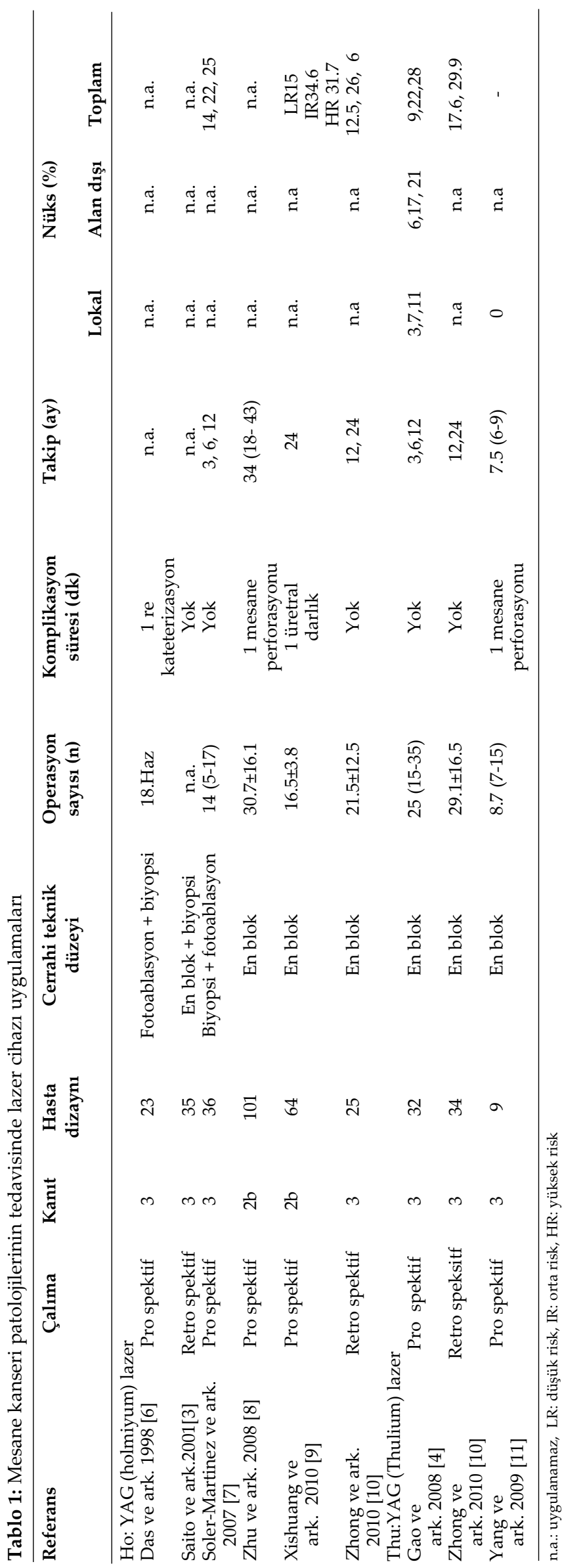

\section{Lithium Borate Laser (Greenlight HPS $₫$, LBO)}

KTP lazer gibi $532 \mathrm{~nm}$ dalga boyunda ışıma yapar. ChinesAmerican Collaboration Group, 2013 yilında LBO ile tedavi edilmiş 74 mesane kanseri olgusunu TUR-MT yapılmış hastalarla karşılaştırmışlar, TUR-MT'ye göre daha düşük komplikasyon ve nüks (\%1.4'e karşı \%7.1) oranı bildirilmiştir (14).

\section{Argon Lazer}

488 - $514 \mathrm{~nm}$ dalga boyuna sahiptir. Üretilen enerji pigmentler, hemoglobin ve melanin tarafından kuvvetli bir şekilde absorbe edilir. Cilt lezyonları ve parsiyel nefrektomide kullanımı mümkündür. Mesane kanserinde ise, sadece küçük papiller lezyonlarda $(<1 \mathrm{~cm})$ kullanılabilir ve ameliyat esnasında koagülasyon nekrozu yaparken derinlemesine penetrasyonu sinırlıdir.

\section{Karbon Diokside (CO2) Lazer}

Doku vaporizasyonuna neden olan $10600 \mathrm{~nm}$ dalga boyunda enerji üretimi sağlar. Su ve optik yüzeylerce emilir, dolayısıyla endoskopik kullanımı oldukça sınırlıdır. Mesane kanseri tedavisinde kullanılmamaktadır.

Lazer ve TUR-MT karşılaştıran yayınların metaanalizi: Son yıllarda lazer ile TUR-MT'yi karşılaştıran birçok çalışma mevcuttur. Çoğu, randomize olmayan az hasta sayılı çalışmalardır. Metaanalizde ameliyat süreleri benzer bulunmuştur. İrrigasyon, kateter ve hastanede kalış süreleri, obturator sinir refleksi ve mesane perforasyonu sonuçları lazer lehinedir. 1 yıllık nükssüzlük oranları benzer; 2 yıllık nükssüzlük oranları lazer tedavisi lehinedir. Lazer vaporizasyonunun lenfatik ve kan damarlarını mühürleyici etkisinden kaynaklandığ 1 düşünülmüştür. İntraoperatif komplikasyonlar, lazer grubunda daha az bulunmuştur (15).

Güncel verilere göre mesane tümörü lazer eksizyon için optimal endikasyonlar; trigonda, yan duvarda veya mesane boynundaki küçük lezyonlardır. Lazer sonrası onkolojik sonuç TUR MT ile benzer bulunmuştur. Ancak uzun dönem sonuçlar mevcut değildir. Deneyimli ellerde mesane patolojilerinin lazer tedavisi, iyi seçilmiş hastalarda geleneksel tedaviye alternatiftir.

Komplikasyonlar ise $<\% 1$ bildirilmiştir. Kanama, perforasyon, üreter ve üretra darllğı, epididimit gibi kompliasyonlar nadir görülür. Fotodinamik tedavi sonrası irritatif bulgular olabilir. Mesane kapasitesinde azalma görülebilir. Penetrasyon derinliği yüksek lazer kullanılırsa kolon ve ince barsak yaralanması mümkün olabilir. Ayrıca lazer, cihazlara zarar verebilir (flex urs hasarı) (Tablo 2).

\section{Renal Tümör İnterstisyel Lazer Ablasyonu}

Küçük böbrek kitlelerinde termal koagülasyon alternatif tedavidir. Yalnizca parsiyel nefrektomiye uygun olmayan, komorbiditeleri olan seçilmiş hasta grubunda uygulanabilir. Klinik deneyim oldukça sınırlıdır. Tabloda iki çalışma özetlenmiştir (Tablo 3).

Renal MR kılavuzluğunda lazer termal ablasyon, ilk kez de Jode tarafından uygulanmıştır (16). Opere edilemeyen 3 hasta tümör Nd:YAG lazerle perkütan, suyla soğutulan interstisyel fiber ile ablate edilmiştir. MR kullanarak lazerin yerleştirilmesine kılavuzluk edilir, tedavi gerçek zamanlı 
Tablo 2: Sonuç ve öneriler (5)

\begin{tabular}{lc}
\hline Sonuçlar & Kanıt düzeyi \\
\hline $\begin{array}{l}\text { KİMK için rezeksiyon, koagülasyon ve } \\
\text { enükleasyonda lazer kullanılabilir }\end{array}$ & 3 \\
$\begin{array}{l}\text { TURB hala altın standart } \\
\text { Uzun dönem nüks ve progresyon oranları belirsiz }\end{array}$ & $1 \mathrm{a}$ \\
$\begin{array}{l}\text { Komplikasyonlar lazerin dalga boyu } \\
\text { (penetrasyon derinliği) ve cerrahi teknik ile ilişkili }\end{array}$ & $\begin{array}{c}\text { Öneri } \\
\text { derecesi }\end{array}$ \\
$\begin{array}{l}\text { Öneriler } \\
\text { Mesane tm için lazer tedavisi klinik } \\
\quad \begin{array}{l}\text { çalışmalarda kullanılmalı veya komorbiditelere } \\
\text { veya diğer komplikasyonlara bağlı geleneksel } \\
\text { tedaviye uygun olmayan hastalarda kullanılmalı }\end{array}\end{array}$ & $\mathrm{C}$ \\
\hline
\end{tabular}

izlenir, doku nekrozu hedef dokuda doğrulanır. Diğer çalışmada Dick ve ark. opere edilemeyen 9 hastada lazer kullanmış, 6 olguda lokal sedasyon ve opiyat analjezisi altında, 3 hasta genel anestezi ile müdahale edilmiş, suyla soğutmalı 600 mikron interestisyel fiber, 1064 mikron Nd:YAG lazer kullanılmış, her tedavi seansında $25 \mathrm{~W}, 10-30$ dakika lazer enerjisi uygulanmıştır. Ortalama 16.9 ay takipte tüm hastalarda tümör küçülmüştür. Çevre dokularda tm yayılımı olmamıştır. 2 olguda periferal hematom gelişmiş ve bunlar konservatif tedavi edilmiştir, 1 olgu gelişen bradikardi, atropinle tedavi edilebilmiştir (17).

EAU kılavuzu sonuç-öneri kısmında lazerle renal tümör ablasyonu; güvenlik ve onkolojik sonuçlar için veriler yetersiz, uzun dönem sonuç yoktur, deneysel bir tedavi olarak kabul edilmelidir, klinik çalışma dışında denenmemelidir (LE 4; Gr C) şeklinde bildirilmektedir (5).

Küçük böbrek kitlelerinin, yaşlı veya komorbiditeleri nedeniyle opere eilemeyen hastalarda radyofrekans ablasyon yöntemiyle tedavisi mümkündür. Lazer, bu tedavi sırasında navigasyon amacıyla da kulanılabilmektedir. 2004 yılında yayınlanan bir makalede bu konuyla ilgili ilk bildirim yapılmıştır (18).

\section{Üst Üriner Sistem TCC'de Lazer Kullanımı}

Tüm TCC'lerin \%5'i üst üriner sistemde görülür. \%60'1 tanı anında invaziftir. \% 1 bilateral eşzamanlı (senkron) görülür. Nefroüreterektomi sonrası karşı ÜÜS'de \%2-9 arasında TCC görülebilir. \%10'u renal pelviste görülür. Altın standart tedavi nefroüreterektomi ve mesaneden cuf çıkarılmasıdır. Düşük dereceli lokal TCC ablatif tedavi ve ardından intrakaviter KT veya immünoterapi ile tedavi edilebilir. Şu durumlarda kullanılması gündeme gelebilir: Fonksiyonel soliter böbrekte TCC, böbrek yetmezliği, ciddi taş hastalığ ve nefroüreterektomiyi engelleyen ciddi medikal komorbiditeler. Tabloda lazerin kullanılabileceği düşük riskli hastalık özellikleri belirtilmektedir. Düşük riskli ÜÜS tümöründe lazerle ablasyon yapılabilir. Hastalar tedavi sonrası yakından izlenmeli ve nüks durumunda standart tedaviye geçilmelidir (5). Resim 2' de düşük ve yüksek riskli üst üriner sistem ürotelyal karsinomunun özellikleri özetlenmiştir. Resim 3'de üst üriner sistem ürotelyal karsinomunda tanısal yaklaşım, risk grubuna göre konservatif yaklaşım uygulanabilecek durumlar ve nüks durumunda yaplacak tedavi özetlenmiştir.

$\mathrm{Bu}$ tümörler için biyopside düşük evreleme yapılması söz konusu olabilir ve eksik tedaviye neden olabilir. Bu konuda bize yardımcı olabilecek başka yöntemler gelişmektedir. Konfokal lazer endomikroskopi ile tümörün derecesi hakkında fikir sahibi olunabileceği bildirilmiştir (19). ÜÜS TCC'de tedavi retrograd üreteroskopik veya antegrad perkütan yaklaşım şeklinde olabilir. Her iki yöntemde de toplayıcı sisteme girip tüm tümörleri ablate etmek ve kanama kontrolü sağlamak mümkündür. İrrigasyon solüsyonu seçimi, kullanılan ablatif yönteme göre değişmelidir, normal SF ile Ho:YAG lazer uygulanabilir. Elektrokoter kullanılacaksa glisin solüsyonu kullanılır ki, sıvı yüklenmesi, hiponatremiye bağlı komplikasyonlar olmasın. Ho:YAG lazerin penetrasyon derinliği $0.4 \mathrm{~mm}$ iken, $\mathrm{Nd}$ :YAG lazerin 5-10 mm penetrasyon derinliği vardır. Lazer seçiminde bu nokta dikkate alınmalıdır. 20 yıl önce tanımlanmış perkütan yöntemle ve elektrokoter kullanılarak ÜÜS-TCC tedavisi düşük evre ve dereceli , <2

Tablo 3: Renal tümör interstisyel lazer ablasyon çalışmaları

\begin{tabular}{lcclcc}
\hline Referans & Hasta (n) & Hastalık & Lazer kaynağı & Yorum & Kanıt düzeyi \\
\hline De Jode ve ark. 1999 [16] & 3 & İnoperabl renal tümörler & Nd:YAG lazer & Perkütan veya MR eşliğinde \\
Dick ve ark. 2002 [17] & 9 & İnoperabl renal tümörler & Nd:YAG lazer & Perkütan veya MR eşliğinde & 3 \\
\hline
\end{tabular}

Tablo 4: Üst üriner sistem transizyonel hücreli karsinomun perkütan lazer ablasyonu

\begin{tabular}{|c|c|c|c|c|c|c|}
\hline Seriler & $\begin{array}{l}\text { Hasta sayıs1/ } \\
\text { ablatif teknik }\end{array}$ & $\begin{array}{l}\text { Düşük derece/ } \\
\text { düşük evre }\end{array}$ & $\begin{array}{l}\text { Yüksek derece/ } \\
\text { yüksek evre }\end{array}$ & Ortalama takip & Sonuçlar & Komplikasyonlar \\
\hline Lee (20) & $\begin{array}{c}50 \text { reTUR ise elektro } \\
\text { rezeksiyon } \\
\text { ile lazer ablasyon }\end{array}$ & 20 & 29 & 46.6 & $\begin{array}{l}\text { Veriler tümöre } \\
\text { özgü, işleme } \\
\text { özgü değil }\end{array}$ & $\begin{array}{l}\text { Kanama } \\
\text { enfeksiyon }\end{array}$ \\
\hline Roupret (21) & $\begin{array}{c}16 \text { ATG Ho:YAG } \\
\text { Nd:YAG } \\
27 \text { RTG } \\
54 \text { NefU }\end{array}$ & $11 / 16(\% 69)$ & $5 / 16(\% 31)$ & 22 & $\begin{array}{c}4 / 16 \text { perk } \\
(\% 25) \rightarrow \text { diğer NefU }\end{array}$ & $2 / 16(\% 12.5)$ \\
\hline Oriheula (22) & $\begin{array}{l}\text { 14; Nd:YAG } \\
\text { reTUR'da }\end{array}$ & belirtilmemiş & belirtilmemiş & 19 & 6 nükssüz & belirtilmemiş \\
\hline
\end{tabular}

ATG: antegrad, RTG: retrograd, NefU nefroüreterektomi, 
Tablo 5: Lokalize PCa'da interstisyel lazer koagülasyon çalışmasında hastalar ve işlemlere ait özellikler

\begin{tabular}{|c|c|c|c|c|c|c|c|}
\hline Hasta & Yaş & PSA & Bx GS & İşlem süresi & $\begin{array}{l}\text { Ablasyon } \\
\text { süresi }\end{array}$ & $\begin{array}{l}\text { Lazer enerji } \\
\text { (W) }\end{array}$ & Son GS \\
\hline 1 & 66 & 9.3 & $3+4$ & 84 & 91 & 12 & $3+2(+4)$ \\
\hline 2 & 58 & 8.5 & $3+3$ & 118 & 91 & 10 & $3+3$ \\
\hline 3 & 67 & 10.2 & $4+3$ & 100 & 91 & 10 & $3+4$ \\
\hline 4 & 60 & 16.2 & $3+4$ & 74 & 81 & 15 & $3+4(+5)$ \\
\hline 5 & 70 & 5.7 & $3+2$ & 59 & 73 & 11 & $3+2(+5)$ \\
\hline
\end{tabular}

Bx: Biyopsi, GS: Gleason Skoru

A

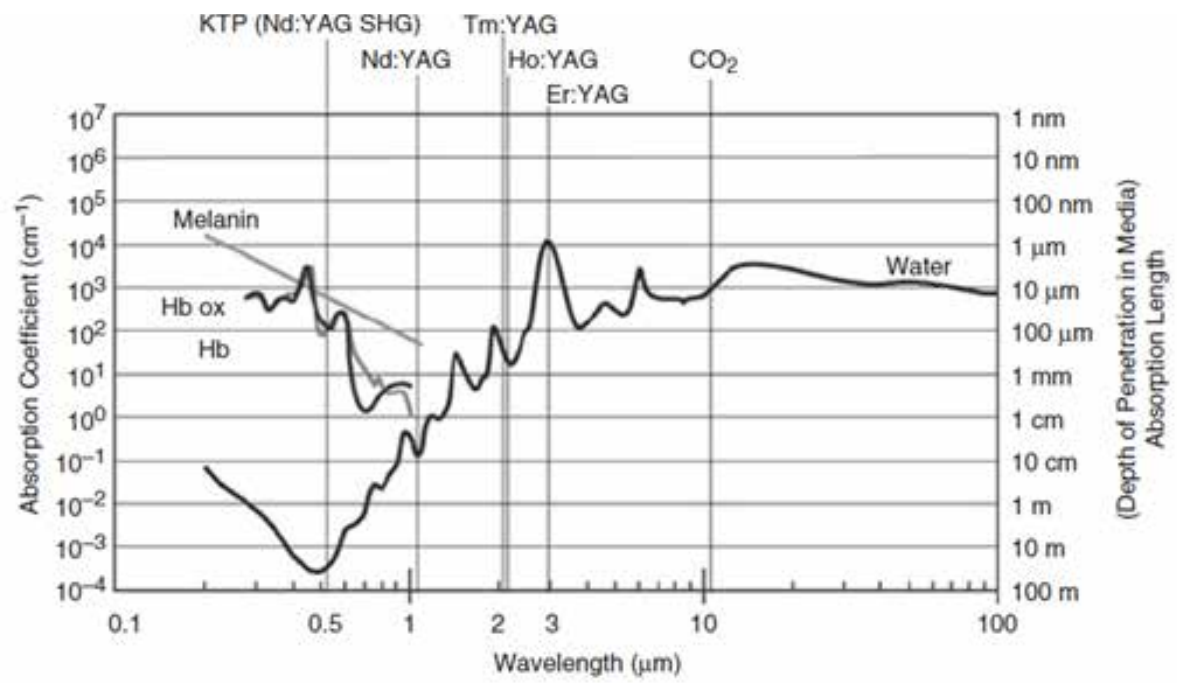

B

Resim 1: Spesifik lazer dalga boylarının melanin, hemoglobin ve suda absorbsiyonu spektrumları (1).

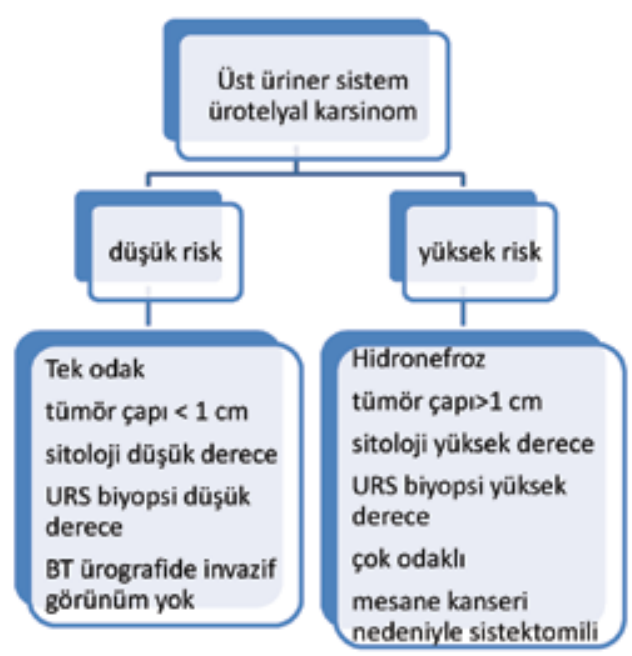

\section{Resim 2: Düşük ve yüksek riskli üst üriner sistem ürotelyal karsinomun özellikleri}

cm tümörler için geçerlidir. Ardından nefrostomiden intrakaviter tedavi ile nüksü önlemek hedeflenir. İkincil bakı ile tam kontrol sağlanır. Güncel tedavi ise cold-cup biyopsi sonrası Ho:YAG lazer ile ablatif tedavidir. İşlemin SF ile yapılması avantaj sağlar. Nd:YAG derin penetrasyon nedeniyle terkedilmiştir.
Üreteral tümörlerde üreteroskopik lazer ablasyon mümkündür ve bazen de zorunludur. Boyutu $<1.5 \mathrm{~cm}$, tek pelvis tümörlerinde daha güvenle uygulanabilir. Büyük veya multiple tümör varlı̆̆ında tek böbrekli hasta için zorunlu olarak perkütan yaklaşım, tümör rezeksiyonu ve tam histolojik değerlendirme yapılabilir.

Endoskopik yaklaşımla; Düşük dereceli tümörler için 5 yıllık hastalığa özgü sağkalım (HÖS) \%82 olarak bildirilmektedir. Yüksek dereceli tümörlerde ise 5 yıllık HÖS \% $47^{\prime}$ dir ve bu yüksek riske girmek gereksizdir. Düşük dereceli tümörler için nefroüreterektomi, üreteroskopik yaklaşım ve perkütan yaklaşım kıyaslandığından 5 yıllık HÖS sırasıyla \%84, \%81, $\% 80$ olarak bildirilmektedir. 5 yıl hastalıksız sağkalım ise sirasıyla \%75, \%71.5 ve \%72'dir, sağkalımlar arasında fark görülmemiştir. Endoskopik tedavi, düşük dereceli tümörler için alternatif olarak önerilebilir. Yüksek dereceli, invazif veya büyük/ çok odaklı düşük dereceli tümörlerde ise nefroüreterektomi önerilmelidir (5) (Tablo 4). Bu seriler özel olarak lazer ablasyonu perkütan antegrad renal yaklaşımla uygulayan verileri içermektedir. Retrograd üreteroskopik yaklaşım ile lazer ve/veya elektrotedavi ile endoskopik tedavi bu tabloda yer almamaktadır.

\section{Yüzeyel TCCde Fotodinamik Tedavi}

Lazer ışığı kullanılarak yüzeyel TCC için fotodinamik tedavi tanısal ve tedavi edici yöntem olarak kullanılabilmek- 


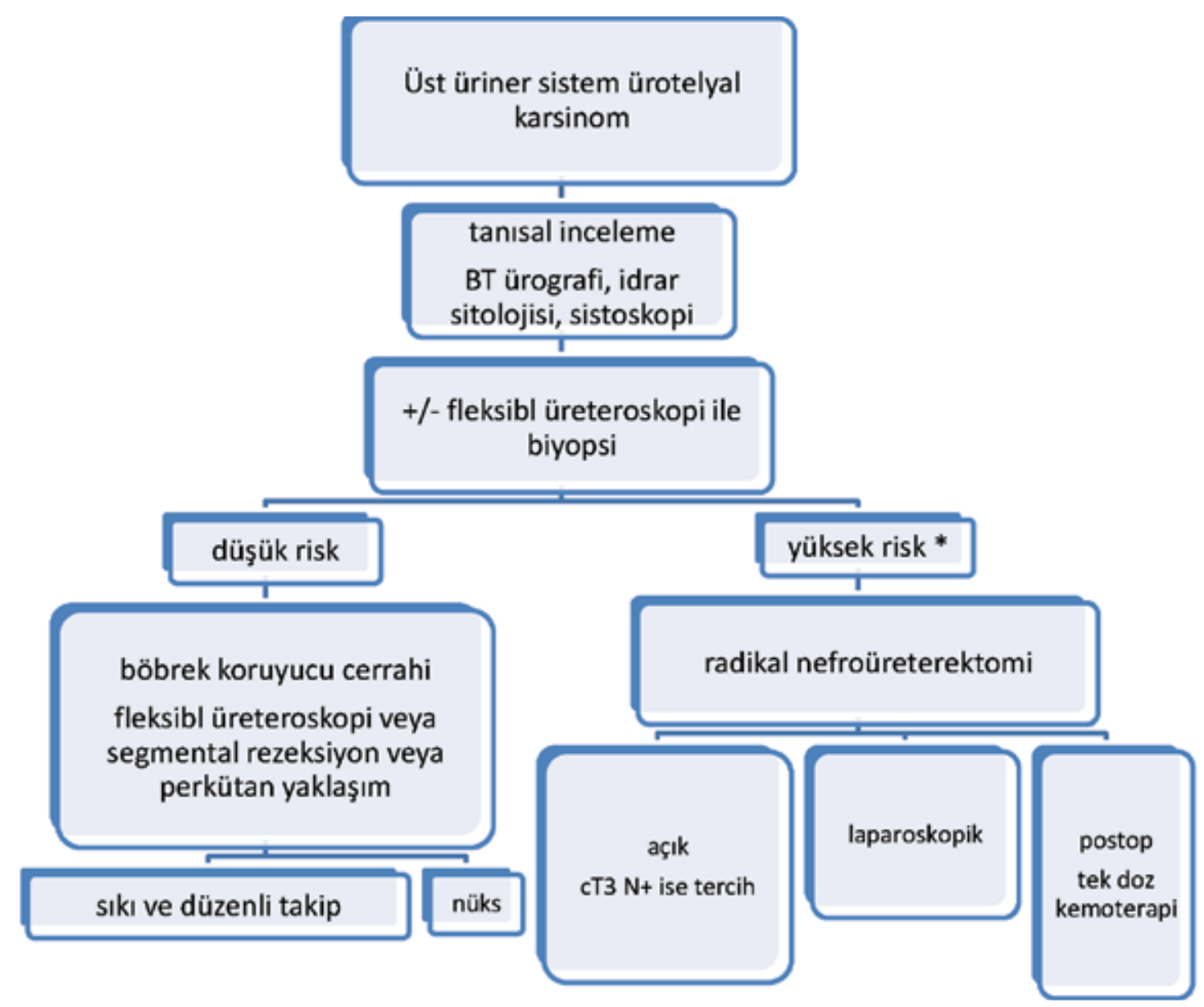

Resim 3: Tek böbrekli hasta için yüksek riskli de olsa konservatif yaklaşım tercih edilebilir.

tedir. İşlem sırasında foto duyarlılaştırıcı ajanla aktivasyon yapılır. İlaç mesaneye verilir, sistoskopiyle uygun dalga boyunda 1şıkla görüntülenir. Birçok fotonduyarlılaştırıcı ajan ile uygun dalga boyu (630-760 nm) nedeniyle, diod lazer bu alanda popülerdir. Başka 1şı kaynakları da kullanılabilir. Fotodinamik tedavi; Prostat kanserinde, RCC'de, penisin malign lezyonlarında da araştırılmıştır. (23-25)

\section{Penis Karsinomu}

Penil SCC'nin histolojisi nedeniyle metastaz riski düşüktür (evreler Tis Ta, T1, grade 1-2). Bu olgularda organ koruyucu yaklaşım olarak lazer ablasyon kullanılabilir (26). En sık CO2 lazer kullanılır. Bazı merkezler Nd:YAG lazerle kombine ederek tümör tabanında doku nekrozunu arttırmıştır (27).

\section{Prostat Ca}

Lokalize PCa için fokal lazer ablasyon (interstisyel lazer koagülasyon) ihtimali araştırılmıştır. Rezeke edilemeyen KC metastazları ve hepatocellüler $\mathrm{Ca}$ için bu tedavi halen uygulanmaktadır. Bu amaçla Nd:YAG lazer veya diode laser kullanılabilir. MR kullanılarak gerçek zamanlı görüntülerle lazerin etkileri izlenebilir (28).

Geçen yıl yayınlanan faz I klinik çalışmada prostat kanserinde fokal lazer ablasyonun sonuçları bildirilmiştir. $\mathrm{Bu}$ çalışma esas olarak transrektal MR kılavuzluğunda yapılan işlemin (in-bore fokal lazer ablasyon) güvenilirliğine odaklanmıştır. MR kılavuzluğunda suyla soğutulan lazer probu kullanilarak 3 dakikaya kadar 10-15 watt enerji ile interstisyel 1sıtma uygulanmıştır. İşlemden 6 ay sonra MR-US füzyon biyopsisi uygulanmış, yan etkiler ve yaşam kalitesi ölçülmüştür. İşlemin uygulandığ1 8 olguda başarı ile tamamlanmış, derece 3 veya üzeri yan etki görülmemiş, IPSS veya IIEF5 skorunda değişiklik izlenmemiştir. Ablasyon bölgesi 3 cc veya prostat hacminin \%7.7'si olarak ölçülmüştür. PSA değeri 7 olguda düşmüştür. Ablasyon bölgesinde 5 olguda biyopsi ile tümör saptanmamış ancak 6 olguda ablasyon bölgesi dışında tümöre rastlanmıştır. Sonuçta daha büyük bir bölgenin ablate edilmesine gereksinim olduğu bildirilmektedir (29).

Benzer hedefleri olan faz 2 çalışmada ise, düşük PSA değeri olan $<15 \mathrm{ng} / \mathrm{ml}$, PSA dansitesi $<0.15$, Gleason skoru 7'den büyük olmayan, toplam biyopsi sayısının \%25'inden azında tümör saptanan ve MR'da 1 veya 2 lezyon saptanan olgular dahil edilmiştir. Ablasyondan sonra 3. ayda MR kılavuzluğunda ablasyon bölgesinden biyopsi alınmış ve patoloji incelenmiştir. Yine 12. ayda MR çekilerek sistematik biyopsi alınmıştır. Ortalama yaşı 62 olan 27 erkek çalışmaya dahil edilmiştir. Ortalama PSA 4.4'tür. Biyopsi Gleason skoru 4 olguda 7 (\%15) ve 23 olguda 6'dır (\%85). Yedi hastada hedeflenen ablasyon zonu dişında düşük hacimli 
Gleason 6 tümör bulunmuştur. İşlemden sonra 3. Ayda 26 olguda (\%96), MR ve biyopsi ile ablasyon bölgesinde tümör saptanmamıştır. IPSS skorunda değişim olmamış ve cinsel işlev skorlarında 1 ve 3 aylarda iyileşme, 12 ayda ise değişim olmadığı görülmüştür. Onikinci ayda MR kılavuzluğunda yapılan biyopside 10 olguda (\%37) tümör saptanmış, bunların 3'ü (\%11) ablasyon bölgesinde, 8'i ablasyon bölgesi dişında (\%30) ve 1'i hem ablasyon bölgesinde hem de bölge dışında saptanmıştır. Sonuçta fokal lazer ablasyonun kısa dönem için iyi tolere edildiği ancak onkoloijik sonuçlar için uzun süreli takibe gereksinim olduğu belirtilmiştir (30). Çoğu düşük risk grubunda olan prostat kanserli olgularda fokal lazer ablasyon ile \%37'si 12. ayda başarısız bulunmuştur, bunların \%30'u ablasyon zonunda, \%80'i bölge dışında ve $\% 10$ birliktedir.

Radikal prostatektomi uygulanacak hastalara, öncesinde fokal lazer ablasyon uygulanmış, sonra final patolojide bu tedavinin etkinliği araştırılmıştır. Bu çalışmada periprostatik blok anestezisi ile ve MR kılavuzluğunda biyopsi alınmıştır. MR ile lezyon belirlenir, iğne kılavuz ile yönlendirilir, $14 \mathrm{G}$ kateter, titanyum trokarla yerleştirilir, içinden lazer gönderilir, sonra trokar çıkarılır, kateter içinde lazer dokuda kalır. Böylece diğer dokular termal hasardan korunur. Çalışmada sadece 5 hasta yer almıştır. Yaş ortalaması 55 yıl, PSA ortalaması $9.8 \mathrm{ng} / \mathrm{ml}$, Gleason skoru 3+3 ile 4+3 arasında, işlem süresi 1.5 saati bulurken ablasyon süresi sadece 1.5 dakika kadardır ve 10-15 watt enerji kullanılmıştır. İşlemden 3 hafta sonra radikal prostatektomi uygulanmıştır (31) (Tablo 5). Bu çalışmada, güvenli sınırlar içinde ablasyon yapılmalı, T1w imajlar daha uygun görüntüleme sağlar, uzun ve düzenli takip sonuçları gereklidir şeklinde sonuçlara ulaşılmıştır.

Özetleyecek olursak, PCa'nın fokal lazer ablasyonu, kanserin çok odaklı olması, ablasyondan sonra tekrar tedavi uygulamaya gereksinim duyulması, ablasyonda tedavi edilememiş odakların olabileceği endişesi, uzun dönem onkolojik sonuçların olmayışı, MR ile gösterilememiş lezyonların olasılığı, final Gleason Skoru'nun yüksek olma ihtimali gibi nedenlerle henüz deneysel aşamadadır.

Malign olmayan genital cilt lezyonlarında da lazer kullanılabilir. Condylomata accuminata prepuce, glans, penil shaft ve intra-uretral oluşabilir. CO2 lazer 1970'lerden beri çok odaklı küçük lezyonların vaporizasyonunda kullanılmaktadır. Büyük condylomata için , Nd:YAG laser ile koagülasyon sonradan gelişmiştir. İntra-uretral lezyonlar $\mathrm{Nd}: \mathrm{YAG}$ veya KTP lazer ile tedavi edilebilir. (32) HIV'li hastalarda onkojenik virüsün dispersiyon riski taşımasından dolayı condilomların lazer vaporizasyonu önerilmez.

\section{Kaynaklar}

1. Teichmann HO, Herrmann TR, Bach T. Technical aspect of lasers in urology. World J Urol;25:221-225, 2007.

2. Staehler G, Schmiedt E, Hofstetter A. Destruction of bladder neoplasms by means of transurethral neodymYAG-laser coagulation. Helv Chir Acta;45:307-311, 1978

3. Saito S. Transurethral en bloc resection of bladder tumors. J Urol;166:2148-50, 2001.

4. Gao X, Ren S, Xu C, et al. Thulium laser resection via a flexible cystoscope for recurrent nonmuscle invasive bladder cancer: initial clinical experience. BJU Int;102:1115-1118, 2008.
5. Herrmann TR, Liatsikos EN, Nagele U, et al. EAU guidelines on laser and technologies, 2014

6. Das A, Gilling P, Fraundorfer M. Holmium laser resection of bladder tumors (HoLRBT). Tech Urol;4:12-14, 1998.

7. Soler-Martinez J, Vozmediano-Chicharro R, MoralesJimenez $\mathrm{P}$, et al. Holmium laser treatment for low grade, low stage, noninvasive bladder cancer with local anesthesia and early instillation of mitomycin C. J Urol;178:2337-2339, 2007.

8. Zhu Y, Jiang $X$, Zhang J, et al. Safety and efficacy of holmium laser resection for primary nonmuscle invasive bladder cancer versus transurethral electroresection: single-center experience.Urology;72:608-612, 2008.

9. Xishuang S, Deyong $\mathrm{Y}$, Xiangyu C, et al. Comparing the safety and efficiency of conventional monopolar, plasmakinetic, and holmium laser transurethral resection of primary non-muscle invasive bladder cancer. J Endourol;24(1):69-73, 2010.

10. Zhong C, Guo S, Tang Y, et al. Clinical observation on 2 micron laser for non-muscle-invasive bladder tumor treatment: single-center experience. World J Urol;28:157161, 2010.

11. Yang Y, Wei ZT, Zhang X, et al. Transurethral partial cystectomy with continueous wave laser for bladder carcinoma. J Urol:182:66-69, 2009.

12. Migliari R, Buffardi A, Ghabin H. Thulium Laser Endoscopic En Bloc Enucleation of Nonmuscle-Invasive Bladder Cancer. J Endourol;29:1258-1262, 2015.

13. He D, Fan J, Wu K, et al. Novel green-light KTP laser en bloc enucleation for nonmuscle-invasive bladder cancer: technique and initial clinical experience. J Endourol;28:975-979, 2014.

14. Tao W, Yang D, Shan Y, et al. Safety and efficacy of $120 \mathrm{~W}$ high performance system greenlight laser vaporization for non-muscle-invasive bladder cancer. J Xray Sci Technol;21:309-316, 2013.

15. Bai Y, Liu L, Yuan H, et al. Safety and efficacy of transurethral laser therapy for bladder cancer: a systematic review and meta-analysis. World J Surg Oncol.;25:12:301, 2014.

16. de Jode MG, Vale JA, Gedroyc WM. MR-guided laser thermoablation of inoperable renal tumours in an open-configuration interventional MR scanner: preliminary clinical experience in three cases. J Magn Reson Imaging;10:545-549, 1999.

17. Dick EA, Joarder R, de Jode MG, et al. Magnetic resonance imaging-guided laser thermal ablation of renal tumours. BJU Int;90:814-822, 2002.

18. Varro Z, Locklin JK, Wood BJ. Laser navigation for radiofrequency ablation. Cardiovasc Intervent Radiol;27:512-515, 2004.

19. Villa L, Cloutier J, Cotte JF, et al. Confocal laser endomicroscopy in the management of endoscopically treated upper urinary tract transitional cell carcinoma: Preliminary data. J Endourol;30:237-242, 2016.

20. Lee D, Trabulsi E, McGinnis D, et al. Totally endoscopic management of upper tract transitional-cell carcinoma. J Endourol;16:37-41, 2002.

21. Rouprêt $\mathrm{M}$, Traxer $\mathrm{O}$, Tligui $\mathrm{M}$, et al. Upper urinary tract transitional cell carcinoma: recurrence rate after percutaneous endoscopic resection. Eur Urol;51:709713, 2007. 
22. Orihuela E, Smith AD. Percutaneous treatment of transitional cell carcinoma of the upper urinary tract. Urol Clin North Am;15:425-431, 1988.

23. Stables GI, Stringer MR, Robinson DJ, et al. Erytroplasia of Queyrat treated by topical aminolevulinic acid photodynamic therapy. Br J Fermatol;140:514-517, 1999.

24. Pomer S, Grashev G, Sinn H, et al. Laser-induced fluorescence diagnosis and photodynamic therapy of human renal cell carcinoma. Urol Int;55:197-201, 1995.

25. Windahl T, Andersson SO, Lofgren L. Photodynamic therapy of localised prostatic cancer. Lancet;336:1139, 1990.

26. Busby JE, Pettaway CA. What's new in the management of penile cancer? Curr Opin Urol;15:350-357, 2005.

27. Windahl T, Andersson SO. Combined laser treatment for penile carcinoma: results after long-term follow-up. J Urol;169:2118-2121, 2003.

28. Lindner U, Lawrentschuk N. Trachtenberg J. Focal laser ablation of localized prostate cancer. J Endourol;24:791-797, 2010.
29. Nataraian S, Raman S, Priester AM, Garritano J, Margolis DJ, Lieu P, Macarian ML, Huang J, Grundfest W, marks LS. Focal lazer ablation of prostate cancer: Phase I clinical trial. J Urol;196:68-75, 2016.

30. Eggener SE, Yousuf A, Watson S, et al. Phase II evaluation of magnetic resonance imaging guided focal laser ablation of prostate cancer. J Urol;196:1670-1675, 2016.

31. Bomers JG, Cornel EB, Fütterer JJ, et al. MRI-guided focal laser ablation for prostate cancer followed by radical prostatectomy: correlation of treatment effects with imaging. World J Urol;35(5):703-711, 2017.

32. Stein BS. Laser treatment of condilomata acuminata. J Urol;136:593-594, 1986.

Yazışma Adresi:

Ferhat Ateş,

SBÜ Sultan Abdülhamid Han Ĕ̆itim ve Araştırma Hastanesi, Üroloji, Anabilim Dall, İstanbul

Tel: +905325566339

e-mail: drferhatates@yahoo.com 